\title{
O PAPEL DA INVESTIGAÇÃO QUALITATIVA EM PSICOLOGIA?
}

\author{
Catarina Brandão', Stella Taquette ${ }^{2}$, Jaime Ribeiro ${ }^{3}$ \\ 'Doutora em Psicologia. Docente na Universidade do Porto. Porto, Portugal. http://orcid.org/0000-0002-4305-5605. \\ catarina@fpce.up.pt.catarina@fpce.up.pt \\ 2Doutora em Saúde da Criança e do Adolescente. Docente na Universidade do Estado do Rio de Janeiro. \\ Rio de Janeiro, Brasil. stella.taquette@gmail.com \\ ${ }^{3}$ Doutor em Multimédia em Educação. Docente no Instituto Politécnico de Leiria. Leiria, Portugual. jribeiro@ludomedia.pt
}

Uma consulta rápida por qualquer manual de investigação qualitativa aplicada à Psicologia permite identificar um conjunto de premissas que respondem por si mesmas à questão que serve de título a este editorial. $O$ paradigma qualitativo e interpretativo é diversificado, anti-positivista, recorre à perspectiva dos indivíduos, privilegia significados e intenção de ação e faz uso de métodos qualitativos, ideográficos e holísticos. Acrescente-se a isso que os trabalhos desenvolvidos à luz deste paradigma quando comparados com o paradigma quantitativo, entendem que a realidade é dinâmica e associada à história específica de cada indivíduo e dos contextos. Neste âmbito, apropriamos-nos das palavras de Leonardo Boff, quando afirma no seu livro "A águia e a galinha: uma metáfora da condição humana" que:

"Todo ponto de vista é a vista de um ponto. Para entender como alguém lê, é necessário saber como são seus olhos e qual é a sua visão do mundo."

Isto é basilar para a Psicologia, enquanto ciência que foca o comportamento, as emoções e as cognições do ser humano, estando preocupada não só com a dimensão da compreensão, mas também com a intervenção, no sentido da melhoria da qualidade de vida de indivíduos, grupos, comunidades e da sociedade em geral.

Ao procurar conhecer os sistemas de crenças e de valores, os sistemas de comunicação e de relação, bem como perceber os significados e as intenções das ações humanas, de forma a integrar a complexidade do mundo social e cultural em que vivemos e salientar a importância da experiência simbólica e subjectiva, a investigação qualitativa permite, no nosso entender, que a Psicologia se afirme e desenvolva enquanto ciência, concretizando os seus objectivos.

O recurso ao paradigma qualitativo permite não só aceder à experiência vivida dos indivíduos, como também agir sobre ela. $O$ processo de investigação promove mudança nos diferentes actores envolvidos, desde o investigador ao participante, que coconstrói a investigação e dá a conhecer o seu mundo subjectivo. A mudança é mobilizada com a presença do investigador no terreno e o seu contacto com os contextos estudados, sendo que algumas metodologias se propõem formal e explicitamente a uma mudança co-construída, como é o caso da investigação-acção. Talvez resida aqui - no potencial para a mudança uma das razões pelas quais continua a aumentar $\circ$ interesse pela Psicologia qualitativa.

Esta edição da Revista Psicologia, Diversidade e Saúde integra sete artigos (em português e espanhol) selecionados entre aqueles que foram apresentados no $6^{\circ}$ Congresso Ibero-Americano em Investigação Qualitativa (www.ciaiq.org). Considerouse a avaliação dos mesmos pela comissão científica do $C I A I Q$, tendo sido sujeitos a ampliação. A seleção considerou ainda os objetivos editoriais da Revista Psicologia, Diversidade e Saúde e, assim, contribuir para o desenvolvimento científico, teórico e metodológico da Psicologia como ciência e profissão. 